\title{
Purification of Pectin Lyase Enzyme from Bacillus pumilus Bacteria by Three-Phase Partitioning Method (TPP), Nanoflower Preparation and Investigation of Fruit Juice Clarification
}

\author{
Aynur Babagil 1, Hayrunnisa Nadaroglu 2,3 (D) \\ 1 Department of Nano-Science and Nano-Engineering, Institute of Science and Technology, Ataturk University, 25240 \\ Erzurum, Turkey; ababagil@ hotmail.com (A.B.); \\ 2 Department of Food Technology, Vocational College of Technical Science, Ataturk University, 25240 Erzurum, Turkey \\ * Correspondence: hnisa25@atauni.edu.tr (H.N.);
}

Scopus Author ID 6506121388

Received: 21.03.2021; Revised: 20.05.2021; Accepted: 25.05.2021; Published: 13.08.2021

\begin{abstract}
In this study, firstly, Bacillus pumilus bacteria were isolated from tomato vegetables and identified. Then, the new pectin lyase enzyme was purified from B. pumilus, characterized, and hybrid nanoflower pectin lyase (hNF-PL) was synthesized the first time in this study. For this purpose, PL enzyme was produced in a solid culture medium using B. pumilus bacterium, and PL was purified in 191.8 folds with a yield of $78.2 \%$ using the three-phase partitioning (TPP) technique. Using SDSPAGE, PL enzyme was determined to have a single subunit, and molecular weight was defined as 32.88 $\mathrm{kDa}$ with gel chromatography technique. This is the very first study to easily immobilize purified PL enzyme onto nanoflower chitosan/calcium pyrophosphate hybrid NPs. The synthesized nanoflower hNF-PL structure was characterized by SEM, FT-IR, XRD, and TEM chromatographic methods. In the final phase of the study, the effects of the pure PL and hNF-PL enzymes on the clarification and cleavage rate of fruit juices obtained from black grape, pomegranate, peach, red apple, and plum were investigated. Under the light shed by this study determined that the hNF-PL enzyme clarified the fruit juices more effectively than the pure PL enzyme.
\end{abstract}

Keywords: pectin lyase (PL); Bacillus pumilus; three-phase partitioning (TPP); hybrid nanoflower pectin lyase (hNF-PL); fruit juice clarification.

(C) 2021 by the authors. This article is an open-access article distributed under the terms and conditions of the Creative Commons Attribution (CC BY) license (https://creativecommons.org/licenses/by/4.0/).

\section{Introduction}

Structural polysaccharides that are present in plant walls and middle lamella are defined as pectic substances. These substances have a molecular weight of $30-300 \mathrm{kDa}$. Most of the pectin is composed of D-galacturonic acid units [1]. Within the structure of pectin, galacturonic acid units are linked by $\alpha-(1,4)$ glycosidic bonds [2-5]. Pectinolytic enzymes break down pectins, a natural polymer of galacturonic acid [5]. Generally, these enzymes are produced in solid culture media. A. niger, A. flavus, A. wentii, A. oryzae, Rhizopus liquefaciens, Geobacillus stearothermophilus (Ah22), Brevibacillus borstelensis (P35), and Penicillum microorganisms are used in the production of PL enzymes. The biosynthesis of pectolytic enzymes is controlled by a catabolic or induction repression mechanism [5-7]. 
An important member of the pectinase enzyme complex is pectin lyase. Pectin lyase (PL, EC 4.2.2.10) is a microorganism that is the main source of PL enzymes, which are industrial enzymes that possess hydrolytic properties. 50\% of them are obtained from fungi and yeast, $35 \%$ from bacteria, and the remaining $15 \%$ from plant or animal sources [7]. Pectin lyase enzymes known today are endogenous [8-10], and methylated galacturonic acid residues occur when they hydrolyze the glycosidic bond [11]. They prefer esterified pectin polymers and contain $\mathrm{Ca}^{2+}$ ions as cofactors [9]. While it is known that PL enzyme can be obtained from bacterial species belonging to the genera of Aspergillus, Rhizopus, Saccharomyces, Bacillus, Kluyveromyces, Erwinia, Penicillium, it is commercially obtained mostly from microorganisms species of the genera Aspergillus, Penicillium, Erwinia, Aspergillus parasiticus [10-15].

Pectinase is used in areas including but not limited to the food industry, processing of plant fibers, textile, paper industry [12-15], vegetable oil extraction [12-15], and the wine industry [16]. Pectinase enzymes are also used for fruit juice extraction and clarification and the prevention of gelation during shelf life in thick fruit juices $[5,6,17,18]$.

To ensure continuous use or re-use of the enzymes by preserving the pure enzyme activity obtained by different methods, they are immobilized on organic or inorganic carriers by using chemical or physical methods [19-21].

When the enzyme is immobilized on the stationary material using the covalent immobilization technique, it may lose its enzyme activity due to its structurally affected active site. As of the 1990s, immobilized enzymes have been shown to protect their activities as much as do pure PL enzymes when immobilized onto nanoscale materials. In 2012, when the first organic-inorganic hybrid nanoflowers (NF) were found to retain the enzyme activity, a great interest has been drawn to the subject [21]. Nano-hybrid structures from nanomaterials are often called nano-flowers because of their flower-like appearance. Although these synthesized flower-shaped hybrid structures are on a micrometer scale per se, they are called nanoflowers just because the leaves that form them are nanoscale [21-23].

In this study, after isolation and molecular identification of B. pumilus bacteria from a tomato plant, PL enzyme was obtained by developing in a solid culture medium. Then, the extracellularly produced PL enzyme was purified by triple-phase separation and characterized. The pure PL enzyme was immobilized on an hNF-PL structure, and its usability in fruit juice clarification was investigated.

\section{Materials and Methods}

\subsection{Bacteria isolation.}

In this study, tomatoes from Erzurum local markets were used for microorganism isolation. A $10 \mathrm{~g} / \mathrm{mL}$ of sampling was made from the work specimen under aseptic conditions, and it was homogenized with a $90 \mathrm{~mL}$ maximum recovery diluent (Merck 1.12535) solution by utilizing Stomacher homogenizer. Serial dilutions from $10^{-1}$ to $10^{-8}$ were prepared using the prepared maximum recovery diluent. Nutrient agar (Merck 1.05450) was spread from each dilution and then incubated at $34^{\circ} \mathrm{C}$ for 48 hours. Nutrient agar medium was drawn from the typical colonies developed after incubation, and plotting was done by drawing 3 phases. This was continued until pure colonies were obtained. The purified colony was then transferred into the nutrient broth (Merck 1.05443) containing a 20\% glycerol solution. It was then stored at $80^{\circ} \mathrm{C}$ as stock culture. 
2.1.1. Identification tests.

In this study, gram staining and catalase tests were performed on isolated microorganisms among general identification tests. According to the results of microbiological analysis, it was found to be gram-positive and catalase-positive.

\subsubsection{Identification of microorganisms.}

After isolation of microorganisms from tomatoes has been carried out, obtained pure cultures were identified at the species level. For this purpose, DNA analysis was performed before pure culture, and then $16 \mathrm{~S}$ rRNA and 16S-23S rRNA gene (ISR) were identified by sequencing.

\subsubsection{Genotype characterization of bacteria.}

For the sequence analysis of the $16 \mathrm{~S}$ rRNA genes, universal primers LPW57 (5 WAGTTTGATCCTGGCTCAG-3 ') and LPW205 (5'-CTTGTTACGACTTCACCC-3 T) [22] were used. In the amplification of the ISR region, 16-1A (GTCGGAATCGCTAGTAATCG) and 23-1B (GGGTTCCCCCATTCGGA) [23] universal primers were used. Sequence analysis was made by Medsantek (Turkey) company. The results of the 16S rRNA and 16S-23S rRNA full sequence analysis of the study with other bacterial sequences in GenBank (http://blast.ncbi.nlm.nih.gov/blast.cgi) were compared, and the similarity ratio was determined [24]. It was determined that the isolate obtained was $99 \%$ similar to Bacillus pumilus bacteria in Genbank.

\subsection{Pectic enzyme production with solid culture fermentation.}

For enzyme production in microorganisms, the solid culture fermentation method was used [25]. Separate media were prepared by adding different amounts of pectin to $250 \mathrm{~mL}$ flasks (pectin ED 85\% -93\%) and 5 grams of bran and $10 \mathrm{ml}$ broth solution $\left(\left(0.14 \%\left(\mathrm{NH}_{4}\right)_{2} \mathrm{SO}_{4}\right.\right.$, $0.2 \% \mathrm{KH}_{2} \mathrm{PO}_{4}$ and $\left.0.02 \% \mathrm{MgSO}_{4}\right)$. Subsequently, these prepared media were sterilized in an autoclave at $121{ }^{\circ} \mathrm{C}$ for 20 minutes. Bacteria were planted in the medium after sterilization and incubated for 5 days at $34{ }^{\circ} \mathrm{C}$ in the oven. After incubation, $60 \mathrm{ml}$ deionized water with $0.9 \%$ $\mathrm{NaCl}$ was added to the medium and mixed with the magnetic stirrer for 1 hour to allow the PL enzyme to pass to the solution phase. The supernatant (growth medium) and the precipitate (bran + microorganism) were separated by centrifugation at $10,000 \times g\left(20 \mathrm{~min}\right.$ at $\left.4{ }^{\circ} \mathrm{C}\right)$. PL activity and protein determination were performed in (pure extract) supernatants [26].

\subsection{Purification of pectin lyase enzyme.}

From Bacillus pumilus bacteria produced in solid culture medium, PL enzyme was purified and characterized by the three-phase partitioning (TPP) technique [27]. For this purpose, first n-butanol optimization and then ammonium sulfate optimization was carried out. Briefly; n-butanol and $8 \mathrm{~g}$ of ammonium sulfate were added to the reaction medium at a ratio of $1: 0.5,1.0: 1.0,1.0: 1.5,1.0: 2.0$. The mixture was stirred for $30 \mathrm{~min}$ in a magnetic stirrer. The resulting solutions were then centrifuged at $6000 \mathrm{x}$ g for $10 \mathrm{~min}$. Three-phase formation in the reaction media was observed, such as supernatant alcohol as the upper phase, precipitate middle phase, and water lower phase (Figure 1). The precipitate middle phase was dissolved in $0.05 \mathrm{M}$ phosphate buffer ( $\mathrm{pH} 8.0$ ) with $1 \mathrm{~mL}$ and dialyzed against the same buffer for 3 hours. 

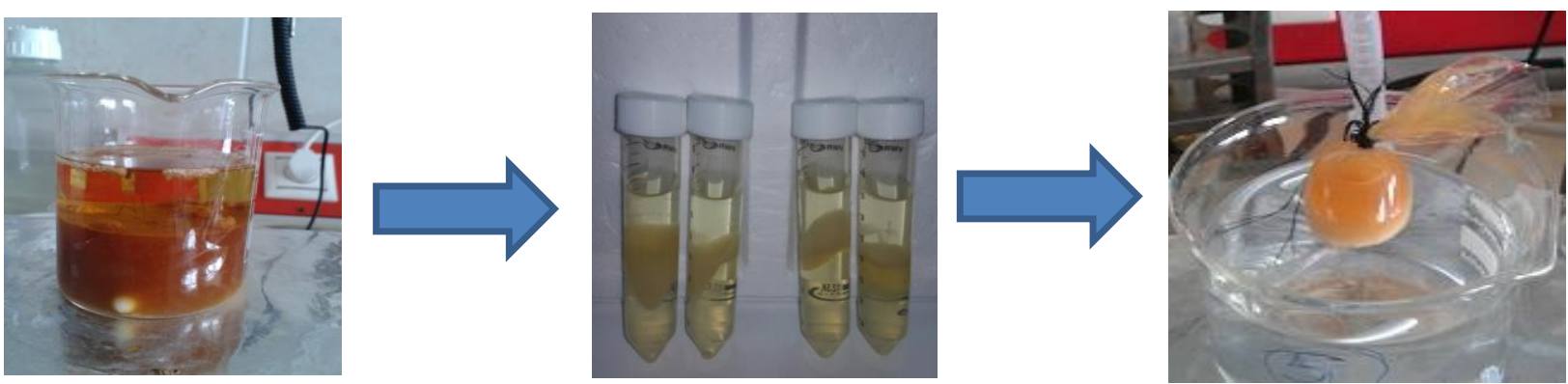

Figure 1. Purification steps of pectin lyase enzyme by the three-phase partitioning (TPP) method.

Enzyme activity was determined using pectin as a substrate at $550 \mathrm{~nm}$. A blank sample was prepared by using phosphate buffer instead of the enzymes.

For ammonium sulphate optimization, pure extract and the optimum ratio of n-butanol (1.0:0.5\%) were determined by adding $20 \%, 40 \%, 60 \%$ and $80 \%$ ammonium sulfate. The highest activity of ammonium sulfate was determined. As per this ratio, the optimum value was determined by a second ammonium sulfate precipitation. Purification of the PL enzyme was carried out according to the obtained parameters.

PL enzyme activity was determined by the method of colored derivation [28]. For pectin lyase activity measurement, the following procedure was followed. A $0.25 \mathrm{~mL}$ of the enzyme solution was added to $0.25 \mathrm{~mL}$ of substrate solution ( $1 \%$ pectin solution) and left at $50{ }^{\circ} \mathrm{C}$ for 10 minutes. Then $50 \mu \mathrm{L}$ of $1 \mathrm{~N} \mathrm{NaOH}$ was added to the $0.5 \mathrm{~mL}$ reaction mixture and incubated for 5 minutes in a water bath at $80{ }^{\circ} \mathrm{C}$ and then cooled to room temperature. A $0.6 \mathrm{~mL}$ of $1 \mathrm{~N}$ $\mathrm{HCl}$ and $0.5 \mathrm{~mL}$ of $0.04 \mathrm{M}$ thiobarbituric acid solution was added to the cooled reaction mixture, incubated for a second time at $80{ }^{\circ} \mathrm{C}$ for 5 minutes, and cooled. The optical density of the obtained colored derivative was measured at $550 \mathrm{~nm}$ by using a UV-VIS spectrophotometer.

\subsubsection{Protein determination.}

Protein content was determined using the Bradford method. For this purpose, $100 \mu \mathrm{L}$ of the enzyme was added to $5 \mathrm{~mL}$ of Coomassie brilliant blue solution. After vortexing, it was kept at room temperature for 10 minutes, and the absorbance value at $595 \mathrm{~nm}$ on the spectrophotometer was measured against the blank sample prepared using pure water instead of the enzyme [29]. Bovine Serum Albumin was used to determine the amount of protein in the enzyme samples.

\subsubsection{SDS-PAGE electrophoresis.}

To determine the subunit number of purified pectin lyase enzyme, sodium dodecyl sulfate-polyacrylamide gel electrophoresis (SDS-PAGE) (5\% aggregate gel and 10\% separation gel) was performed.

\subsubsection{Determination of optimum $\mathrm{pH}$ and stable $\mathrm{pH}$ values.}

The optimum $\mathrm{pH}$ values of pure and hybrid PL enzymes were determined by activity measurements with appropriate buffer systems at the $\mathrm{pH}$ range of 3-11. For this purpose; sodium acetate ( $\mathrm{pH}$ : 3.0-5.0), phosphate $(\mathrm{pH}$ 6.0-8.0), Tris- $\mathrm{HCl}$ buffer $(\mathrm{pH}: 9.0-10.0)$ and sodium carbonate buffer ( $\mathrm{pH} 11.0)$ were used. Activity measurements were made against a blank sample prepared with pure water instead of the enzyme [26]. 
Activity measurements were made between $\mathrm{pH}$ 3.0-11.0 to determine the $\mathrm{pH}$ stability of pure PL and hybrid PL enzymes. In different buffer systems (3-11), the reaction media prepared with pectin substrate were sampled for 1 week, and the stability of enzyme samples was determined [26].

\subsubsection{Determination of optimum and stable temperature values.}

In order to determine the optimum temperature value of the purified PL enzyme, activity measurements were made in the range of $0-90^{\circ} \mathrm{C}$. Blank sample measurements were also determined using pure water instead of the enzyme at each temperature value. For determining the stable temperature of the enzyme; Activity measurements were made every 15 minutes for 2 hours in the range of $10-90{ }^{\circ} \mathrm{C}$. All measurements were performed against the blind sample [30].

\subsubsection{Determination of $\mathrm{V}_{\max }$ and $\mathrm{K}_{\mathrm{M}}$ values.}

Maximum velocities of pure PL and hybrid PL enzymes $\left(\mathrm{V}_{\max }\right)$ and rate constants $\left(\mathrm{K}_{\mathrm{M}}\right)$ were determined by activity measurements against 5 different concentrations of three different substrates (pectin, locus bean gum, and chitin). Vmax and $\mathrm{K}_{M}$ values of Lineweaver and Burk graphs were calculated for this purpose [31].

\subsubsection{Effect of metal ions on pectin lyase activity.}

Two different concentrations of $\mathrm{Ca}^{2+}, \mathrm{Cu}^{2+}, \mathrm{Mg}^{2+}, \mathrm{Zn}^{2+}, \mathrm{Hg}^{2+}$, and $\mathrm{Fe}^{3+}$ ions were measured on the activity of pure PL and hybrid PL enzymes. \% Activity values were calculated from the findings [32].

\subsection{Synthesis of nanoflower pectin lyase $\mathrm{Ca}^{2+}$ hybrid structure.}

Nanoflower chitosan structure was synthesized by the ionotropic gelation method. Briefly, chitosan (CS) was dissolved in $1 \%$ acetic acid solution $\left(2 \mathrm{mg} \mathrm{mL}^{-1}\right)$.

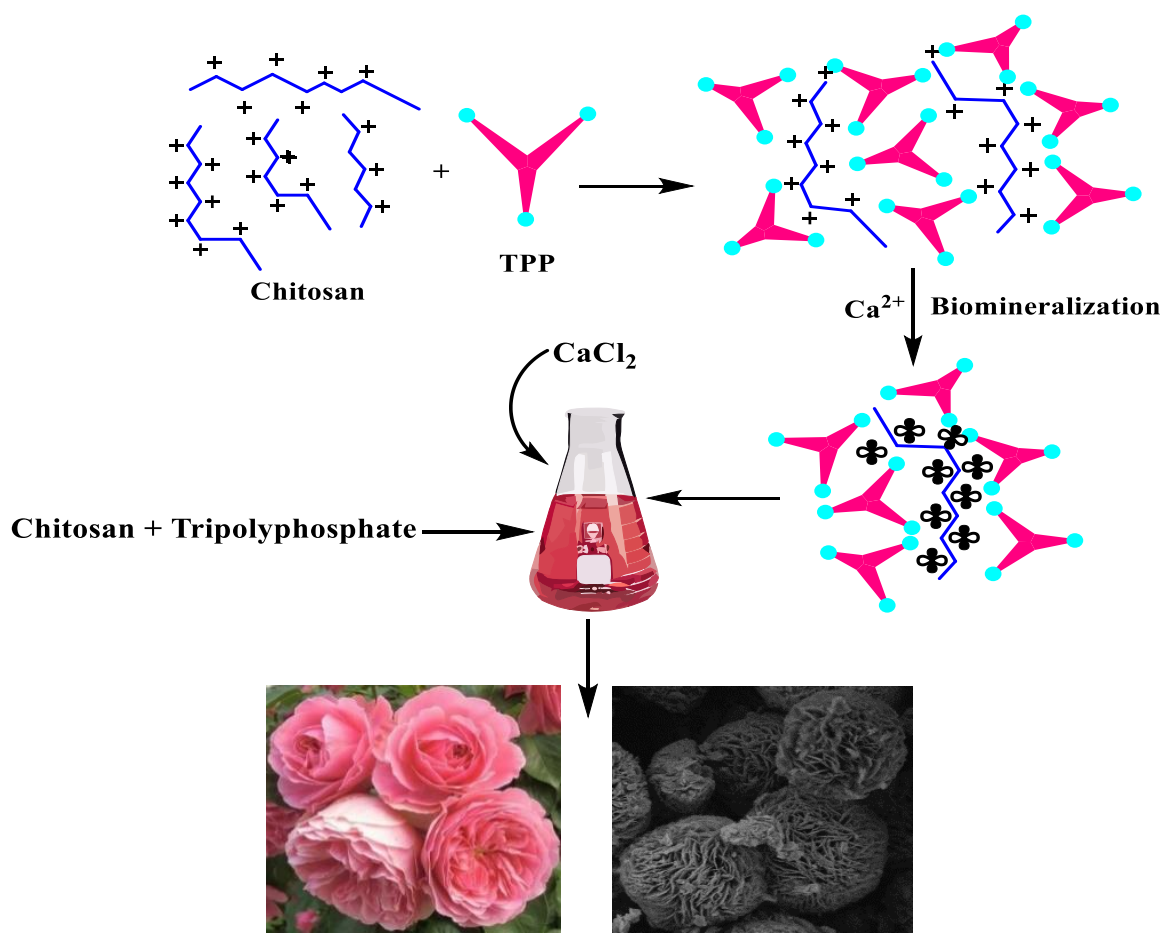

Figure 2. Synthesis steps of hNF-PL enzyme. 
To the CS solution, $1.2 \mathrm{~mL}\left(125 \mathrm{mg} \mathrm{mL}^{-1}\right)$ of TPP solution was added and stirred for 10 minutes. Then, $4.2 \mathrm{~mL}$ of $100 \mathrm{mM} \mathrm{CaCl}_{2}$ was added, and the mixture was stirred for a further 10 minutes at room temperature, and $2.5 \mathrm{ml}$ of purified PL enzyme was added. One day after waiting at room temperature, the protein was determined in the supernatant. After centrifugation, the precipitate was washed with purified water to remove unbound proteins. The synthesized hybrid nano flower PL structure was dried at $37^{\circ} \mathrm{C}$ and characterized (Figure 2) with pure PL enzyme [4].

\subsection{SEM, EDX, XRD, FT-IR, and TEM characterization in hNF-PL enzyme.}

SEM, EDX, FT-IR, and TEM chromatographic analyzes were used to characterize hNF-PL enzyme structures [33].

\subsection{Applications of pure PL and hNF-PL enzymes in fruit juice clarification.}

Fresh fruits (black grape, pomegranate, cornelian cherry, peach, red apple, and plum) bought from local markets were used in fruit juice clarification experiments. Pure PL and hybrid PL enzyme were added to each fruit juice medium and incubated for 5 hours at $50{ }^{\circ} \mathrm{C}$. In the fruit juices produced as a result of the clarification process, fragmentation rate and clarification rate was determined and recorded in percentages [26].

\section{Results and Discussion}

\subsection{Characterization of $L A B$.}

In this research, general identification techniques and molecular techniques were used for the identification of test isolates. As per general identification methods, the test isolate was rod-shaped, gram-positive, and catalase-positive. Obtained results were consistent with the results obtained from the literature [34,35]. In the molecular identification method, 16S-rRNA gene and 16S-23S rRNA intergenic spacer regions (ISR) were identified by means of sequence analysis. This sequence analysis results show that B. pumilus have a high percentage $(99 \%)$ of resemblance to this isolate when compared to other bacterial series in GenBank. Parvathi et al. [36] also reported similar 16S rDNA gene sequence results as (99-100\%).

Table 1. Purification and yield profile of PL enzyme purified from B. pumilus bacteria by TPP method

\begin{tabular}{|c|c|c|c|c|c|c|c|}
\hline Steps & $\begin{array}{l}\text { Volume } \\
(\mathbf{m L})\end{array}$ & $\begin{array}{l}\text { Activity } \\
\text { (EU/mL) }\end{array}$ & $\begin{array}{l}\text { TotalActi } \\
(\mathbf{E U} / \mathbf{m L})\end{array}$ & $\%$ & $\begin{array}{c}\text { SpecificA } \\
\text { ctivity } \\
\text { (EU/mL) }\end{array}$ & $\begin{array}{l}\text { Protein Amount } \\
(\mu \mathrm{g} \text { protein } / \mathrm{mL})\end{array}$ & $\begin{array}{c}\text { Purification } \\
\text { Fold }\end{array}$ \\
\hline Pure Extract & 60 & $233.4 \pm 1.14$ & $14007.3 \pm 3.24$ & 100 & 0.17 & $1340.7 \pm 2.07$ & ----- \\
\hline $\begin{array}{l}\text { n-Butanol } \\
(1: 0.5)\end{array}$ & 20 & $210.2 \pm 2.12$ & $4219 \pm 1.59$ & 90 & 1.09 & $192.4 \pm 1.09$ & 6.41 \\
\hline $\begin{array}{l}1^{\text {st Ammonium }} \\
\text { sulphate } \\
\text { precipitation } \\
(60 \%)\end{array}$ & 20 & $187.5 \pm 0.44$ & $3750 \pm 1.41$ & 80.3 & 4.57 & $41 \pm 0.47$ & 26.9 \\
\hline $\begin{array}{l}2^{\text {nd }} \text { Ammonium } \\
\text { Sulphate } \\
\text { precipitation } \\
(75 \%)\end{array}$ & 20 & $182.6 \pm 1.11$ & $3652 \pm 1.17$ & 78.2 & 32.6 & $5.6 \pm 0.16$ & 191.8 \\
\hline
\end{tabular}

3.2. Purification of the pectin lyase from B. pumilus.

PL enzyme was purified by using TPP method in three steps from B. pumilus the first 
time. In the first step, the maximum PL enzyme activity value was determined in a 1:0.5 ratio (extract: n-butanol). In the second step, at the optimum n-butanol concentration, the $1 \mathrm{st}$ ammonium sulfate saturation was made between $20 \%$ and $80 \%$. The highest activity was obtained at $60 \%$. In the third step, 2nd ammonium sulfate saturation was performed at the optimum 1:0.5 n-butanol ratio and at $65-75 \%$ ammonium sulfate concentration, and the highest activity was determined at the rate of $75 \%$ ammonium sulfate. Purifications were carried out under these conditions. Using TPP method, PL enzyme from B. pumilus bacteria was purified with a yield of $78.2 \%$ in 191.8 folds (Table 1).

In another study, alkaline PL obtained from Aspergillus flavus MTCC 7589 bacteria by using traditional chromatographic methods (Sephadex G-100 gel filtration chromatography) was reported to have been purified 58.01 folds [37]. Extracellular PL enzyme produced by $B$. pumilus (P9) bacteria in solid culture fermentation was reported to be purified 36.36 folds using DEAE-cellulose anion exchange column chromatography [5,26]. Demir et al. (2011) reported that extracellular PL produced by Geobacillus stearothermophilus Ah22 bacteria in solid culture fermentation medium was purified 40.8 folds using DEAE-cellulose anion exchange column chromatography. In an experiment by [27] Sharma and Gupta, tert-butanol was added to the medium where ammonium sulfate is present, and the three-phase partitioning (TPP) technique was used to purify the pectinase enzyme from Aspergillus niger and tomato. According to the research findings, $76 \%$ yield, 10-fold purification, and 183\% yield, and 9fold purification were achieved from Aspergillus niger fungi and tomato, respectively.

SDS-PAGE analysis was performed to determine the number of subunits of the PL enzyme purified from $B$. pumilus, and a single band at $32.88 \mathrm{kDa}$ level was observed. The molecular weight of the pure PL enzyme was also controlled by gel filtration chromatography (Figure 3).

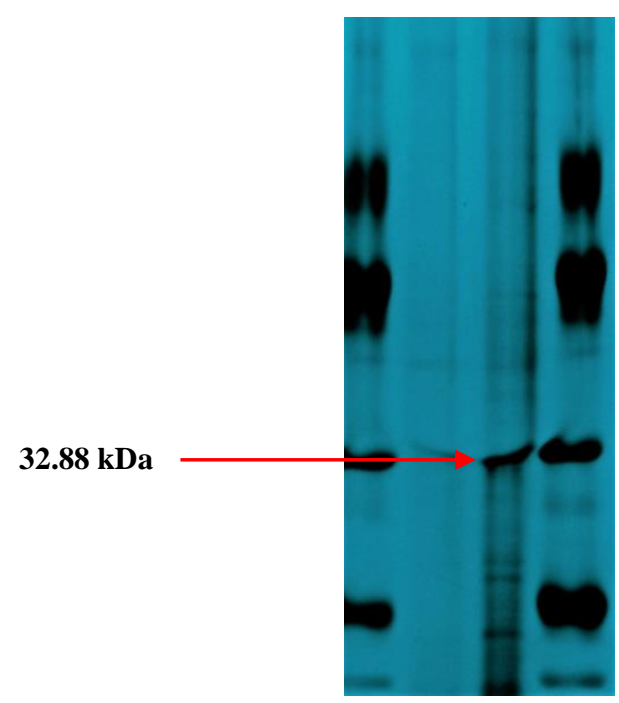

Figure 3. SDS-PAGE electrophoresis gel image of PL enzyme purified by TPP from B. pumilus bacteria.

PL enzyme from B. pumilus (P9), Aspergillus flavus MTCC 7589, and Penicillum chrysogenum bacteria was produced and purified using ion-exchange chromatography technique, and according to SDS-PAGE results; the molecular weight of the enzymes were determined as $25 \mathrm{kDa}, 38 \mathrm{kDa}$, and $31 \mathrm{kDa}$, respectively [26,37,38].

3.3. Synthesis and characterization of the hNF-PL enzyme structure. 
Hybrid structures with chitosan support material were generated to immobilize the PL enzyme that we obtained to provide a more stable structure. These hybrid enzymes were structurally characterized using SEM, TEM, XRD, and FT-IR chromatographic techniques.
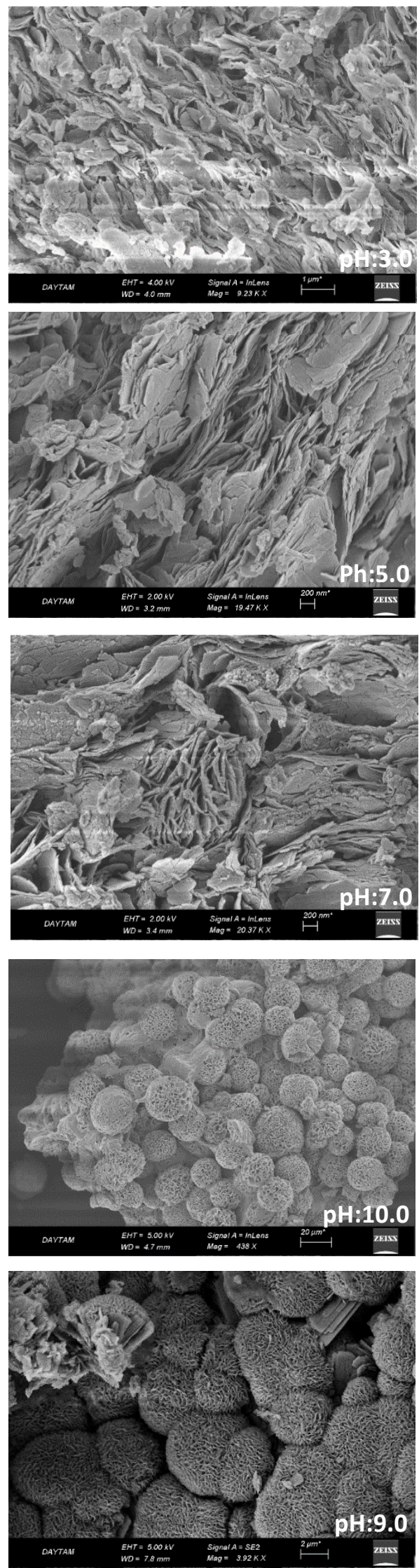
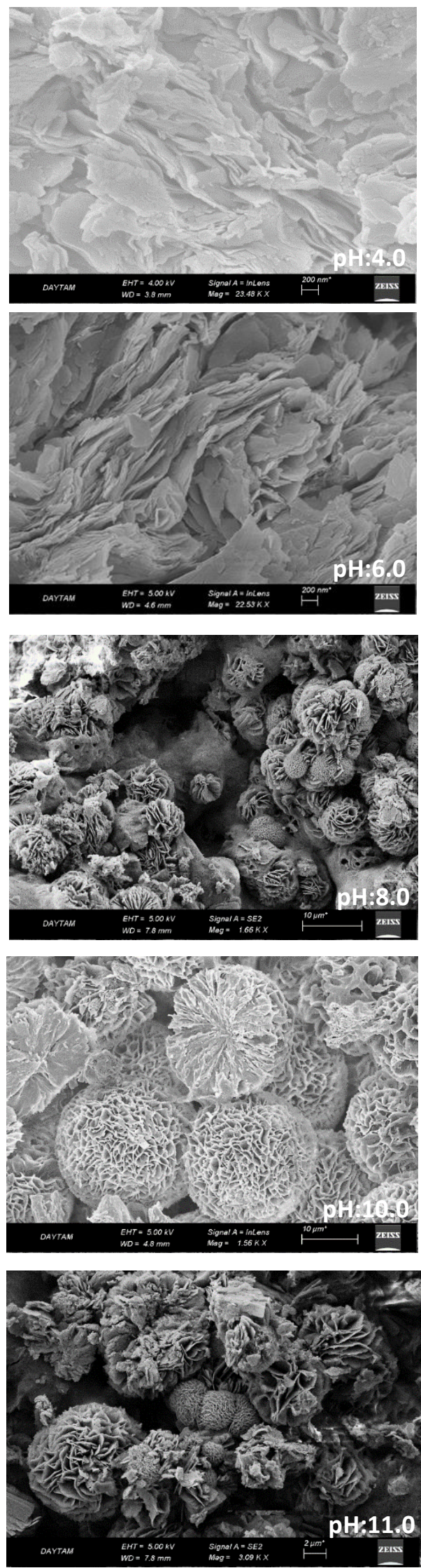

Figure 4. SEM images of hNF-PL structures at different $\mathrm{pH}$ (3-11). 


\subsubsection{Result of SEM analysis.}

Hybrid nanoscale PL enzyme morphology was carried out using Zeiss brand Sigma 300 model scanning electron microscope (SEM). hNF-PL enzyme was synthesized at different $\mathrm{pH}$ values (Figure 4). As pH values approach $\mathrm{pH} 10$, NF formation got better and reached the best condition at $\mathrm{pH} 10$, beyond which the nanoflower structure was observed to have deformed. The results of EDX spectroscopy were given in Figure 5. It was determined that the nanoflower hybrid PL structure was composed of O (48.2\%), P (18.6\%), Ca (16.1\%), and Na (6.1\%). The atomic ratio of $\mathrm{P}$ to $\mathrm{Ca}$ was calculated to be 1.483 .

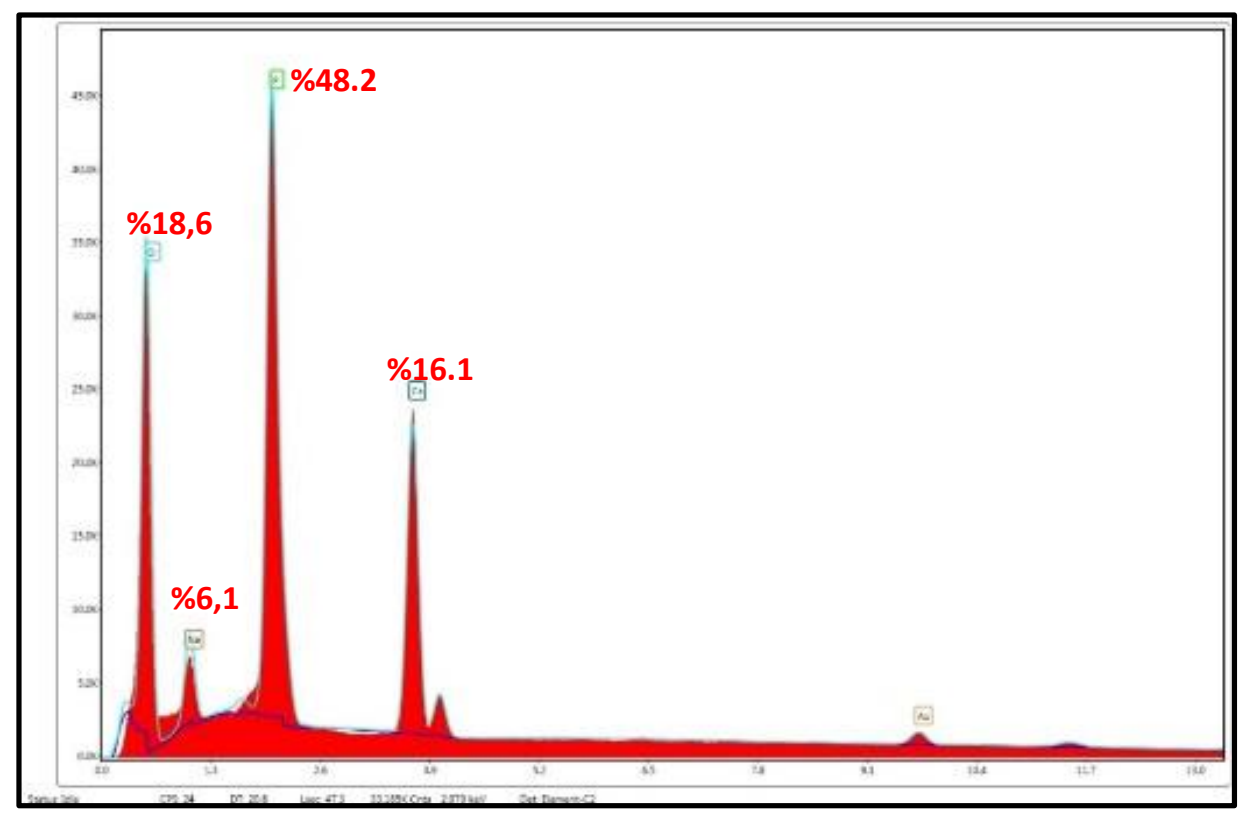

Figure 5. EDX image of hNF-PL structure.

In a study [4], by using catalase enzyme chitosan - tripolyphosphate (CS-TPP) nanomicro flowers (nano complexes) were synthesized by ionotropic gelation. In the SEM-EDX analysis, the presence of $\mathrm{C}, \mathrm{O}, \mathrm{P}$, and $\mathrm{Ca}$ elements was determined. The atomic ratio of $\mathrm{P}$ to $\mathrm{Ca}$ was 1.448. The findings in this research support our results.

\subsubsection{Result of XRD analysis.}

The spectra of XRD analysis of the hNF-PL enzyme structure was shown in Figure 6. The peaks at $7.2^{\circ}$ and $14.5^{\circ}$ in the graph of the hNF-PL enzyme showed chitosan structure, and the peaks at $19.4^{\circ}, 25.2^{\circ}, 29.0^{\circ}, 30.4^{\circ}, 31.1^{\circ}, 41.0^{\circ}, 50.5^{\circ}, 66.3^{\circ}$, and $71.3^{\circ}$ showed tripolyphosphate, $\mathrm{Ca}^{2+}$, and carbohydrate units in the PL enzyme [39]. The obtained findings confirmed that the structure of the hNF-PL enzyme had formed successfully.

\subsubsection{Result of FT-IR analysis.}

The FT-IR spectrum of the hybrid NF PL enzyme structure was presented in Figure 7. The peak seen at $511 \mathrm{~cm}^{-1}$ in the FT-IR spectrum of hNF-PL enzyme belonged to the $\mathrm{P}_{3} \mathrm{O}_{10}{ }^{5-}$ ion. $\mathrm{P}_{2} \mathrm{O}_{7}{ }^{4-}$ ion gave the peak at $758 \mathrm{~cm}^{-1}$. The peaks at the $918-758-692 \mathrm{~cm}^{-1}$ range belonged to POP, and 3483-1656 $\mathrm{cm}^{-1}$ range belonged to $(\mathrm{O}-\mathrm{H})(\mathrm{HOH})$. Our findings are consistent with the analysis of the chitosan calcium hybrid structure reported by Wang [39]. 


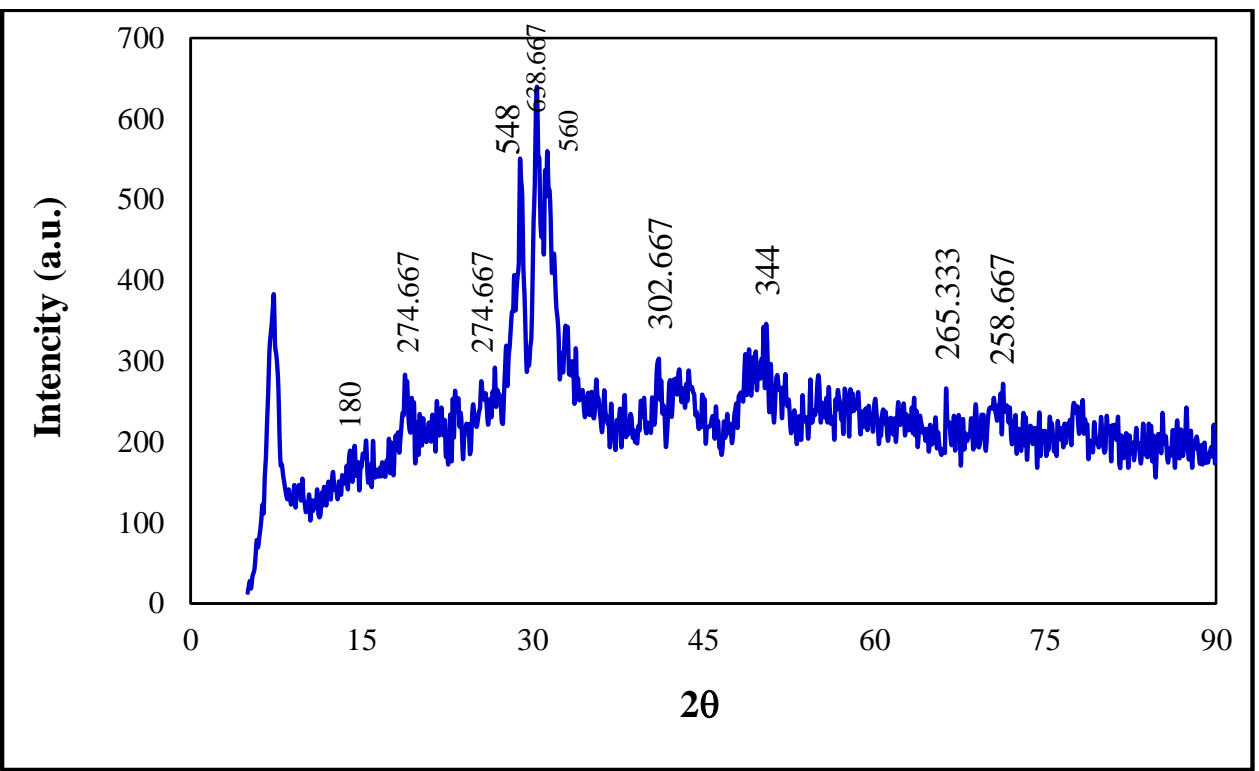

Figure 6. XRD analysis graph of hNF-PL enzyme structure.

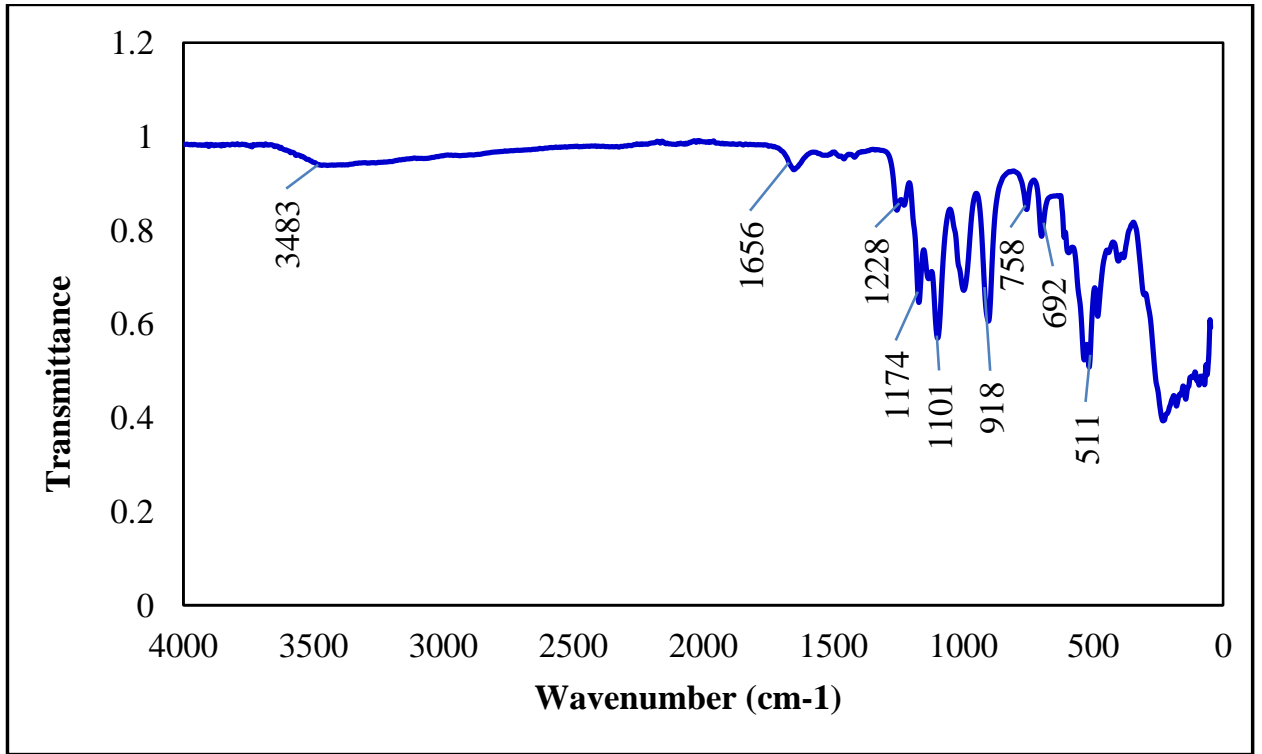

Figure 7. FT-IR analysis graph of hNF-PL enzyme structure

\subsubsection{Result of TEM analysis.}

TEM images of hNF- PL enzyme structures obtained using Transmission Electron Microscope (TEM) are given in Figure 8. According to the TEM images, it was determined that the synthesized nanoflower hybrid PL structures are composed of spherical-shaped nanoparticles and are highly porous and hierarchical structures.

Wang et al. [4], using catalase enzyme, have synthesized chitosan micro tripolyphosphate (CS-TPP) nanoflowers (nano complexes) by an ionotropic gelation method. They reported that the nanoflower structures of the TEM images they obtained consist of porous and hierarchical structures, and they support the findings we obtained.

\subsection{Characterization of $P L$ and $h N F-P L$ enzymes.}

\subsubsection{Optimum $\mathrm{pH}$ and stable $\mathrm{pH}$.}


Enzyme activity measurements were performed between $\mathrm{pH}$ 3-11 in order to determine the optimum $\mathrm{pH}$ values and stable $\mathrm{pH}$ values of pure enzyme and hNF-PL enzymes. The results are given in Figure 9A. The optimum for both pure PL and hNF-PL enzymes was determined to be $\mathrm{pH}$ 8.0, whereas hNF-PL was more stable and active than the pure PL enzyme. It was determined that both pure PL and hNF-PL enzymes showed a sharp loss of activity at pH values below 7.0 and above $\mathrm{pH} 9.0$.

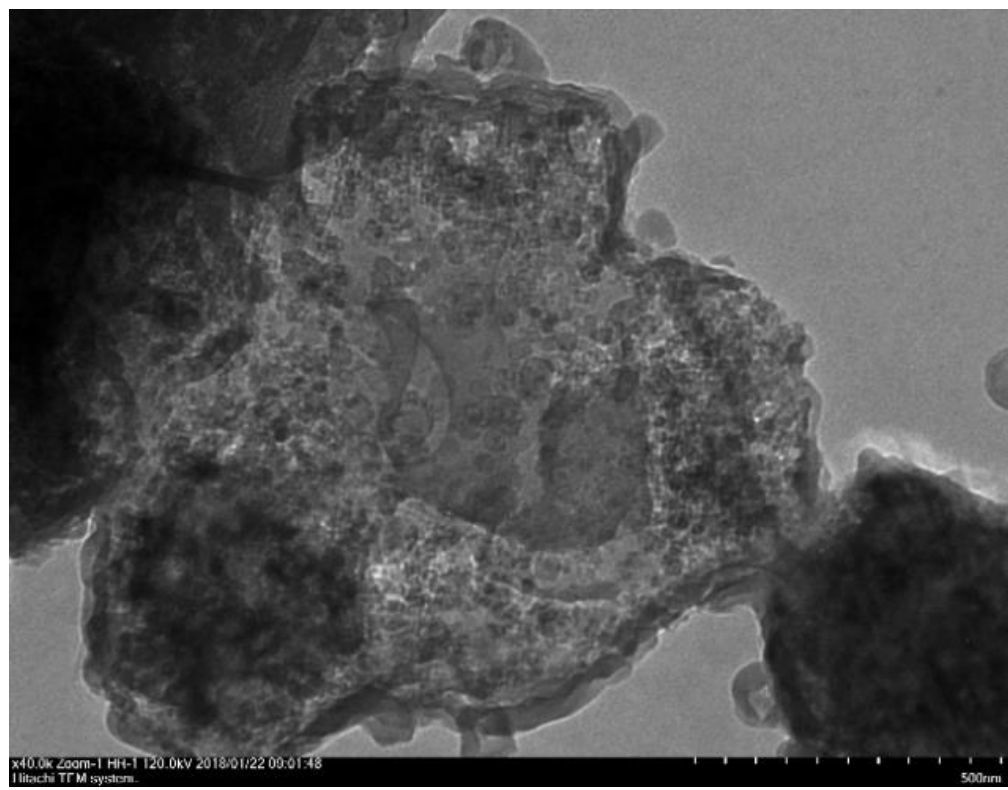

Figure 8. TEM analysis results of hNF-PL structure ( $\mathrm{pH}: 10$, room temperature).

To determine the $\mathrm{pH}$ stability of the pure PL and hNF-PL enzyme, daily activity measurements between $\mathrm{pH}$ 3.0-11.0 were carried out during 1 week (Figure 9B-C). Evaluating the findings, it was determined that pure PL enzyme and hNF-PL enzyme were more stable and had higher activity at $\mathrm{pH} 9.0$ and $\mathrm{pH} 8.0$, respectively.
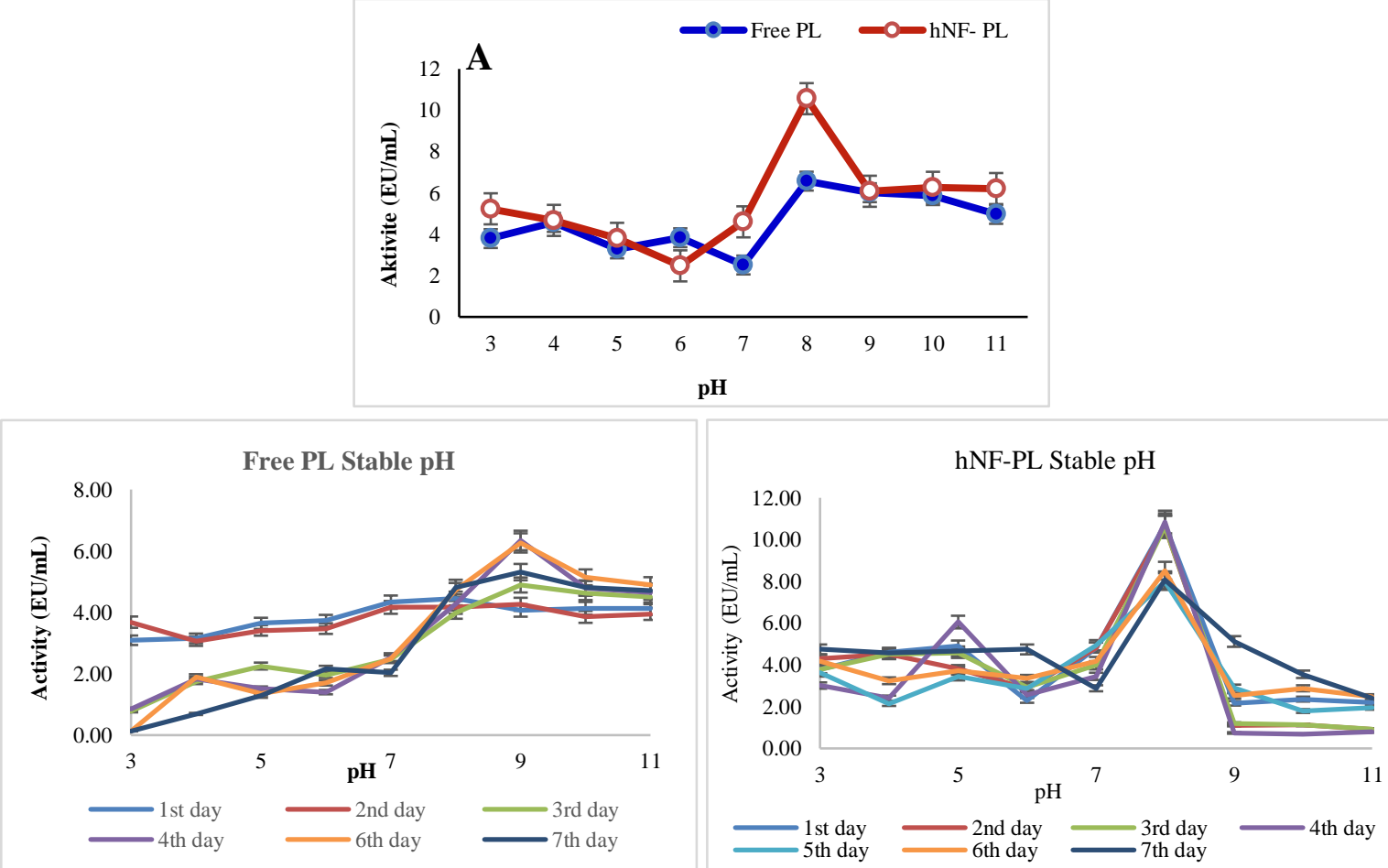

Figure 9. Effect of $\mathrm{pH}$ on activity (A) Optimum $\mathrm{pH}$; (B) Pure PL enzyme stable $\mathrm{pH}$; (C) hNF-PL enzyme stable $\mathrm{pH}$.

3.4.2. Optimum temperature and stable temperature. 
The effect of temperature on pure PL and hNF-PL enzymes between $10-90{ }^{\circ} \mathrm{C}$ was investigated. According to the results obtained, pure PL and hNF-PL enzymes showed maximum activity at $50{ }^{\circ} \mathrm{C}$ (Figure 10A).

When the effect of temperature on the stability of pure PL and hNF-PL enzymes (10 $90{ }^{\circ} \mathrm{C}$ ) was investigated for 2 hours, pure PL was determined to be most stable at $50{ }^{\circ} \mathrm{C}$ and hNF-PL at $60{ }^{\circ} \mathrm{C}$. The figure for hNF-PL to be greater is attributed to its structural properties, which allows it to be more stable in higher temperatures (Figure $10 \mathrm{~B}-\mathrm{C}$ ).

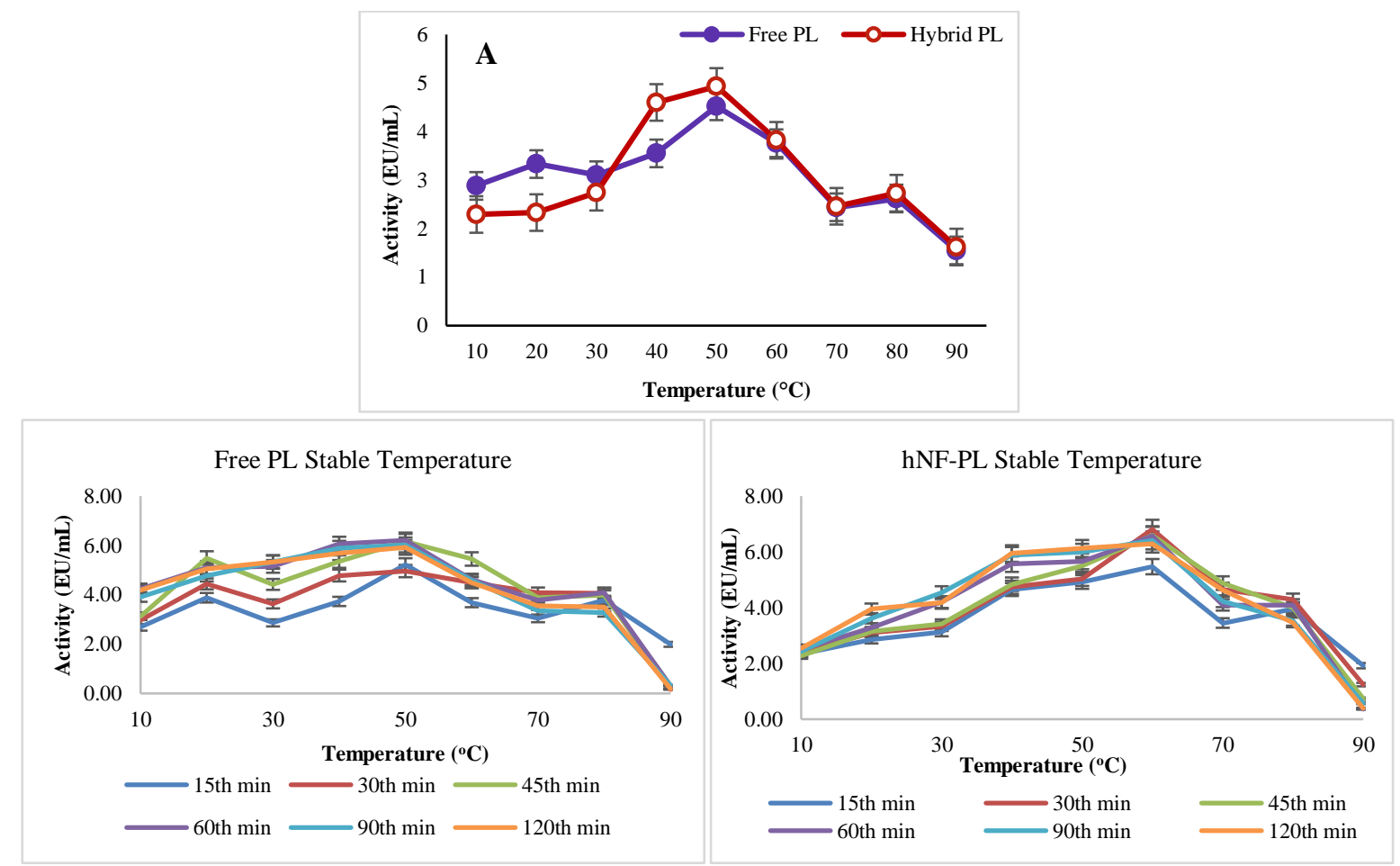

Figure 10. Effect of temperature on activity (A) Optimum temperature; (B) Pure PL enzyme stable temperature;

(C) hNF-PL enzyme stable temperature.

The optimum $\mathrm{pH}$ values obtained from characterization studies of PL enzymes which were purified from B. pumilus (P9), Aspergillus flavus MTCC 7589, and Aspergillus fumigatus 2101 microorganisms, were determined to be $\mathrm{pH} 6.0, \mathrm{pH} 8.0$, and $\mathrm{pH} 8.0$, respectively. Optimum temperatures were found to be $60{ }^{\circ} \mathrm{C}, 50{ }^{\circ} \mathrm{C}$ and $40{ }^{\circ} \mathrm{C}$ respectively $[26,37,40]$.

\subsubsection{The Effect of metal 1ons on pure PL and hNF-PL enzymes.}

The effects of $\mathrm{Ca}^{2+}, \mathrm{Cu}^{2+}, \mathrm{Mg}^{2+}, \mathrm{Zn}^{2+}, \mathrm{Hg}^{2+}$, and $\mathrm{Fe}^{3+}$ metal ions, in the concentration of $1 \mathrm{mM}$ and $5 \mathrm{mM}$, on pure PL and hNF-PL enzyme activities were investigated and the results were given in Table 2 in percentage activity values. According to the findings, the presence of these metal ions activated both pure PL and hNF-PL enzymes.

Table 2. Effect of $\mathrm{Ca}^{2+}, \mathrm{Cu}^{2+}, \mathrm{Mg}^{2+}, \mathrm{Zn}^{2+}, \mathrm{Hg}^{2+} \mathrm{Fe}^{3+}$ metal ions on the activity of pure PL and hNF-PL enzyme

\begin{tabular}{|c|c|c|c|c|}
\hline \multirow[t]{2}{*}{ Chemicals } & \multicolumn{2}{|c|}{$\%$ Pure PL Activity } & \multirow{2}{*}{\multicolumn{2}{|c|}{$\begin{array}{crr}\% & \text { hNF-PL } & \text { Activity } \\
& 1 \mathrm{mM} & 5 \mathrm{mM}\end{array}$}} \\
\hline & $1 \mathrm{mM}$ & $5 \mathrm{mM}$ & & \\
\hline Control & 100 & 100 & 100 & 100 \\
\hline $\mathrm{Ca}^{2+}$ & 160 & 186 & 173 & 198 \\
\hline $\mathrm{Cu}^{2+}$ & 139 & 146 & 150 & 165 \\
\hline $\mathrm{Fe}^{3+}$ & 161 & 184 & 144 & 167 \\
\hline $\mathbf{M g}^{2}$ & 133 & 146 & 148 & 157 \\
\hline $\mathrm{Zn}^{2+}$ & 129 & 135 & 136 & 144 \\
\hline $\mathrm{Hg}^{2+}$ & 0 & 0 & 0 & 0 \\
\hline
\end{tabular}


$\mathrm{Ca}^{2+}, \mathrm{Cu}^{2+}, \mathrm{Mg}^{2+}, \mathrm{Zn}^{2+}, \mathrm{Hg}^{2+}$ and $\mathrm{Fe}^{3+}$ metal ions activated pure PL enzyme by $60 \%$, $39 \%, 33 \%, 29 \%$ and $61 \%$ respectively at the concentration of $1 \mathrm{mM}$, and by $86 \%, 46 \%, 46 \%$, $35 \%$ and $84 \%$, respectively at $5 \mathrm{mM}$ concentration. As for hNF-PL enzyme, $73 \%, 50 \%, 48 \%$, $36 \%$ and $44 \%$ at a concentration of $1 \mathrm{mM}$ and $98 \%, 65 \%, 57 \%, 44 \%$ and $67 \%$ at $5 \mathrm{mM}$ were achieved for the same. $\mathrm{Hg}^{2+}$ metal ion was found to completely inhibit both pure PL and hNFPL enzymes. The highest activity in the hNF-PL enzyme was determined as $98 \%$ against $\mathrm{Ca}^{2+}$ metal ion.

In a previous study, the effect of various metal ions at a concentration of $10 \mathrm{mM}$ on the PL enzyme purified from Bacillus pumilus (P9) was investigated. While $\mathrm{Hg}^{2+}, \mathrm{Mn}^{2+}$, EDTA, and SDS were found to inhibit PL enzyme completely, $\mathrm{Cu}^{2+}, \mathrm{Fe}^{3+}$, and $\mathrm{Zn}^{2+}$ inhibited metal ions by $89 \%, 32.7 \%, 12.1 \%$, respectively. $\mathrm{Ca}^{2+}$ and $\mathrm{Mg}^{2+}$ metal ions were determined to activate by $32.1 \%, 19.2 \%$, respectively [26].

In a study by Banu et al. [38], the effect of various metal ions at a concentration of 5 $\mathrm{mM}$ on the pectinase enzyme purified from the Penicillum chrysogenum bacteria was investigated. It was determined that $\mathrm{Hg}^{2+}, \mathrm{Cu}^{2+}$, and $\mathrm{Co}^{2+}$ metal ions inhibited the enzyme by $58.77 \%, 59.5 \%$, and $58.5 \%$, respectively, while $\mathrm{Ca}^{2+}$ metal ion activated the same by $3.56 \%$. Also, $\mathrm{Zn}^{2+}$ and $\mathrm{Mg}^{2+}$ metal ions have been reported to inhibit enzyme activity by $16.21 \%$ and $26.56 \%$, respectively.

In the study conducted by Cheng et al. [41] on the endo-polygalacturonase enzyme activity purified from the Penicillium oxalicum CZ1028 bacteria, the effects of various metal ions at $1 \mathrm{mM}$ and $2 \mathrm{mM}$ concentration on the enzyme activity were investigated. $\mathrm{K}^{+}, \mathrm{Mg}^{2+}$, and $\mathrm{Ba}^{2+}$ were slightly inhibited, whereas $\mathrm{Cu}^{2+}$ and $\mathrm{Mn}^{2+}$ very strongly inhibited the enzyme activity.

\subsubsection{The effect of Vmax and KM on pure PL and hNF-PL enzymes.}

Activity measurements were made at 5 different substrate concentrations for pectin, locust bean gum, and chitin substrates, and Lineweaver-Burk graphs were drawn by plotting the obtained $1 / \mathrm{S}$ values versus $1 / \mathrm{V}$ values. $\mathrm{K}_{\mathrm{M}}$ and $\mathrm{V}_{\max }$ values were calculated through these graphs (Table 3).

Table 3. $V_{\max }$ and $\mathrm{K}_{\mathrm{M}}$ values of pure PL and hNF-PL enzymes for the substrates of pectin, locust bean gum, and chitin.

\begin{tabular}{l|l|l|l|l|l|l} 
& \multicolumn{2}{l}{ Pectin } & Locust bean gum & \multicolumn{2}{l}{ Chitin } \\
\cline { 2 - 7 } & $\mathbf{V}_{\max }$ & $\mathbf{K}_{\mathbf{M}}$ & $\mathbf{V}_{\max }$ & $\mathbf{K}_{\mathbf{M}}$ & $\mathbf{V}_{\max }$ & $\mathbf{K}_{\mathbf{M}}$ \\
\cline { 2 - 7 } & $(\mu \mathbf{m o l} / \mathbf{L m i n})$ & $\mathbf{( m g / m L})$ & $(\mu \mathbf{m o l} / \mathbf{L m i n})$ & $(\mathbf{m g} / \mathbf{m L})$ & $(\boldsymbol{\mu m o l} / \mathbf{L m i n})$ & $(\mathbf{m g} / \mathbf{m L})$ \\
\hline Pure PL & 17.98 & 0.94 & 1.3 & 0.88 & 1.42 & 0.64 \\
\hline hNF-PL & 20.12 & 0.86 & 2.97 & 0.8 & 3.25 & 0.6
\end{tabular}

In a study conducted by $\mathrm{Lu}$ et al. [42], the exo-polygalacturonase enzyme from Zygoascus hellenicus $\mathrm{V} 25$ was purified, and the $\mathrm{K}_{\mathrm{M}}$ and $\mathrm{V}_{\max }$ values of the polygalacturonase were determined to be $5.44 \mathrm{mg} / \mathrm{mL}$ and $61.73 \mu \mathrm{mol} /(\mathrm{min} \mathrm{mg})$, respectively. Nadaroğlu et al. [26] reported the $\mathrm{K}_{\mathrm{M}}$ and $\mathrm{V}_{\max }$ values as $0.298 \mathrm{mg} / \mathrm{mL}$ and $132.6 \mathrm{pmol} / \mathrm{Lmin}$, respectively, for pectin lyase enzyme purified from Bacillus pumilus (P9). $\mathrm{K}_{\mathrm{M}}$ and $\mathrm{V}_{\max }$ values for PL enzyme purified from Geobacillus stearothermophilus Ah22 were determined to be $0.47 \mathrm{mg} / \mathrm{mL}$ and $355.3 \mu \mathrm{mol} / \mathrm{Ldak}$, respectively, by Demir et al. in 2011 [5].

The hNF-PL enzyme was found to show more activity against pectin, locust bean gum, and chitin substrate than did pure PL enzyme. By using, The $\mathrm{V}_{\max }$ and $\mathrm{K}_{\mathrm{M}}$ values of hNF-PL enzyme were; $20.12 \mu \mathrm{mol} / \mathrm{Lmin}$ and $0.86 \mathrm{mg} / \mathrm{mL}$, respectively for pectin substrate; 2.97 
$\mu \mathrm{mol} / \mathrm{Lmin}$ and $0.8 \mathrm{mg} / \mathrm{mL}$, respectively for locust bean gum substrate; and $3.25 \mu \mathrm{mol} / \mathrm{Lmin}$ and $0.6 \mathrm{mg} / \mathrm{mL}$, respectively for chitin substrate. As seen in Table $3, \mathrm{~V}_{\max }$ and $\mathrm{K}_{\mathrm{M}}$ values of hNF-PL differ from those of pure PL enzyme. For a pectin lyase enzyme in nanoflower structure, the $V_{\max }$ value is was observed to have increased while $K_{M}$ value decreased, which is evidence for the increased affinity of the enzyme for pectin substrates. It is possible to interpret that the increase in $\mathrm{V}_{\max }$ value was due to the fact that the hNF-PL enzyme was more stable than the other structure [50].

\subsection{The results of pure PL and $h N F-P L$ enzymes in the fruit juice production process.}

The efficiency of pure PL and hNF-PL enzymes in fruit juice production and their usability in clarification processes were investigated. For this purpose, black grape, pomegranate, cornelian cherry, peach, apple, and plum obtained from the local markets of Erzurum-Turkey were pureed and treated with pure PL and hNF-PL enzymes. It was compared with the blank reaction medium prepared with pure water instead of an enzyme. When the amount of fruit fiber obtained after separation of the filtrate in the sample was compared, the highest rate of degradation of the fibers and cells in the samples was occurred in the apple sample by $38.3 \%$ for pure PL and $42.6 \%$ for hNF-PL (Table 4 ).

Table 4. Dry matter (D.M.) fragmentation rate of fruit purees added with pure PL and hNF-PL enzyme samples purified from B. pumilus, with reference to the control sample

\begin{tabular}{c|l|l|l|l}
\multicolumn{2}{c}{ Fruit amount (100 g) } & Control & Pure PL & hNF-PL \\
\hline \multirow{3}{*}{ Black Grape } & D.M. (g) & 3.8 & 3.5 & 3.4 \\
\cline { 2 - 5 } & Decrease \% & - & 7.9 & 10.5 \\
\hline \multirow{3}{*}{$\begin{array}{c}\text { Pomegranate } \\
\text { Cornelian } \\
\text { cherry }\end{array}$} & D.M. (g) & 4.2 & 3.2 & 3.1 \\
\cline { 2 - 5 } & Decrease \% & - & 23.8 & 26.2 \\
\cline { 2 - 5 } Peach & Decrease \% & - & 4.8 & 4.2 \\
\hline \multirow{2}{*}{ Apple } & D.M. (g) & 3.3 & 7.7 & 19.2 \\
\cline { 2 - 5 } & Decrease \% & - & 3 & 2.3 \\
\hline \multirow{2}{*}{ Plum } & D.M. (g) & 4.7 & 9.1 & 30.3 \\
\cline { 2 - 5 } & Decrease \% & - & 2.9 & 2.7 \\
\cline { 2 - 5 } & D.M. (g) & 3.2 & 38.3 & 2.7 \\
\cline { 2 - 5 } & Decrease \% & - & 3 & 15.6
\end{tabular}

According to the results of spectrophotometric measurements of the reaction media at $660 \mathrm{~nm}$, the application in which the highest clarity rates were observed was the production of peach juice by $76.6 \%$ and $78.7 \%$ for pure PL and hNF-PL, respectively (Table 5).

Table 5. Reduction in absorbance at $660 \mathrm{~nm}$ in fruit juices obtained from fruit purees added with pure PL and hNF-PL obtained from $B$. pumilus

\begin{tabular}{l|l|l|l}
\multirow{2}{*}{ Fruit } & \multicolumn{3}{|l}{ \% Reduction in absorbance at 660 nm } \\
\cline { 2 - 4 } & Kontrol & Pure PL & Hybrid PL \\
\hline Black Grape & 100 & 42 & 49 \\
\hline Pomegranate & 100 & 32.8 & 42.5 \\
\hline $\begin{array}{l}\text { Cornelian } \\
\text { cherry }\end{array}$ & 100 & 55.9 & 70.6 \\
\hline Peach & 100 & 76.6 & \\
\hline Apple & 100 & 73.3 & 78.7 \\
\hline Plum & 100 & 43 & 46.1
\end{tabular}

In a study conducted by Demir et al. [5], in the clarification experiments of fruit juices (apple, orange, peach, and banana) carried out by adding PL enzyme obtained from 
Geobacillus stearothermophilus Ah22 bacteria, fragmentation rate in dry matter, in percentage to the control sample, in apple, orange, peach and banana juices were determined to be $30.8 \%$, $53.3 \%, 34.6 \%$, and $71.8 \%$ respectively [43]. The highest fragmentation rate was observed in banana juice, with a yield of $71.8 \%$.

Sojitra et al. immobilized 3 enzymes, $\alpha$-amylase, pectinase, and cellulose, on the aminofunctional magnetic nanoparticle via the glutaraldehyde intermediate arm and used it in fruit juice clarification [44-46]. With the use of this magnetic immobilization system comprised of three enzymes, apple, grape, and pineapple fruit juice production with 150 min treatment yielded a reduction of turbidity by $41 \%, 46 \%$, and $53 \%$, respectively. Although three separate enzymes were employed in the combination, their results were lower than those achieved in this study [47-49].

\section{Conclusions}

Microbial enzymes are widely used in different industries because of their high yields, high stability, and economic advantages. Pectin lyase enzyme, which is in the commercial hydrolase enzyme group, and has a 70\% industrial market share, is widely used in the food industry. In this study, 16S-RRNA gene and 16S-23S rRNA intergenic spacer regions (ISR) were identified by means of sequence analysis and isolated from tomato vegetables, and it was determined that the bacteria belonging to B. pumilus species was found to have a similarity of $99 \%$. The extracellular production of the PL enzyme was achieved in a solid culture medium with $B$. pumilus bacteria, and the PL enzyme was first time purified by using the TPP technique with a high yield. In the immobilization of purified PL isoenzyme, hNF-PL was synthesized and characterized for the first time with the ionotropic gelation method. In the final stage of the study, using both free and hNF-PL enzymes, some fruit juices were clarified, and hybrid PL enzyme was found to be effective, hence increasing the yield more than free PL enzyme. The higher stability and effectiveness of hNF-PL are attributed to the greater surface area of its structure. In this respect, the hNF-PL structure is considered suitable to be used in different enzyme systems, in various industrial fields, especially in the food industry, without any inhibition.

\section{Funding}

This research received no external funding.

\section{Acknowledgments}

After the isolation of microorganisms was carried out in Microbiology Laboratory in Department of Food Processing, Vocational College of Technical Science, Ataturk University, the identification of pure cultures at species level has been carried out in the Biotechnology Laboratory of Department of Food Engineering, Erciyes University, with the help of Prof.Dr. Zulal KESMEN within the scope of the thesis titled "Purification and Characterization of Pectin Lyase Enzymes from Microorganism, Preparation of $\mathrm{Ca}^{2+}$-Hybrid Nanoflower Structure and The Investigation of Its Uses in Fruit Juice Clarification", 2018. This study was supported by the Scientific Research Projects Unit of Atatürk University within the scope of Project No 2016/140. 


\section{Conflicts of Interest}

The authors declare that there are no conflicts of interest regarding the publication of this study.

\section{References}

1. Mukhiddinov, Z.K.; Khalikov, D.K.; Abdusamiev, F.T.; A. C.C. Isolation and structural characterization of a pectin homo and ramnogalacturonan. Talanta 2000, 53, 171-176. https://doi.org/10.1016/S00399140(00)00456-2.

2. Levigne, S.; Ralet, M.-C.; Thibault, J.-F. Characterisation of pectins extracted from fresh sugar beet under different conditions using an experimental design. Carbohydrate Polymer 2002, 49, 145-153.

3. Mohare, Y.S.; Pratapwar, A.S.; Sakarkar, D.M.; Sheikh, A. Natural polymers used in sustained drug delivery systems. American Journal of Pharmeceutical Research 2013, 3, 4238-4261.

4. Wang, X.; Shi, J.; Li, Z.; Zhang, S.; Wu, H.; Jiang, Z.; Yang, C.; Tian, C. Facile one-pot preparation of chitosan/calcium pyrophosphate hybrid microflowers. ACS Applied Materials \& Interfaces 2014, 6, 14522 14532. https://doi.org/10.1021/am503787h.

5. Cao, L.; Lu, W.; Mata, A.; Nishinari, K.; Fang, Y. Egg-box model-based gelation of alginate and pectin: A review. Carbohydrate Polymer 2020, 242, 116389. https://doi.org/10.1016/j.carbpol.2020.116389.

6. Demir, N.; Nadaroglu, H.; Tasgin, E.; Adiguzel, A. Gulluce, M.;Purification and characterization of a pectin lyase produced by Geobacillus stearothermophilus $\mathrm{Ah} 22$ and its application in fruit juice production. Annals Microbiology 2011, 61, 939-946. https://doi.org/10.1007/s13213-011-0217-6.

7. Demir, N.; Nadaroglu, H.; Demir, Y.; Isık, C.; Taskin, E.; Adiguzel, A.; Gulluce, M. Purification and characterisation of an alkaline pectin lyase produced by a newly isolated Brevibacillus borstelensis (P35), and its applications in fruit juice and oil extraction. European Food Research and Technology 2014, 239, 127-135. https://doi.org/10.1007/s00217-014-2198-8.

8. Auclair, J.; Gagné, F. The influence of polystyrene nanoparticles on enzyme clusters of fumarate, malate dehydrogenase and citrate synthase: a fractal analysis study. Letters in Applied NanoBioScience 2020, 9, 981987. https://doi.org/10.33263/LIANBS92.981987.

9. Anisa, S.K.; Girish, K. Pectinolytic Activity of Rhizopus sp. and Trichoderma viride. International Journal of Research in Pure and Applied Microbiology 2014, 4, 28-31.

10. Sinitsyna, O.A.; Fedorova, E.A.; Semenova, M. V.; Gusakov, A. V.; Sokolova, L.M.; Bubnova, T.M.; Okunev, O.N.; Chulkin, A.M.; Vavilova, E.A.; Vinetsky, Y.P.; Sinitsyn, A.P. Isolation and Characterization of Extracellular Pectin Lyase from Penicillium canescens. Biochemistry, 2007, 75, 699-706.

11. Abd El-Rahim, W.M.; Moawad, H.; Hashem, M.M.; Gebreil, G.M.M.; Zakaria, M. Highly efficient fungal pectinase and laccase producers among isolates from flax retting liquor. Biocatalysis and Agricultural Biotechnology 2020, 25, 101570. https://doi.org/10.1016/j.bcab.2020.101570.

12. Yener, F. Pektinaz enziminin farklı iki destek üzerine immobilizasyonu ve karakterizasyonu, Yüksek Lisans Tezi. Çukurova Ü 2007.

13. Favela-Torres, E.; Volke-Sepúlveda, T.; Viniegra-González, G. Production of hydrolytic depolymerising pectinases. Food Technology and Biotechnology 2006, 44, 221-227.

14. Ribeiro, D.S.; Henrique, S.M.B.; Oliveira, L.S.; Macedo, G.A.; Fleuri, L.F. Enzymes in juice processing: A review. International Journal of Food Science and Technology 2010, 45, 635-641. https://doi.org/10.1111/j.1365-2621.2010.02177.x.

15. Yang, G.; Chen, W.; Tan, H.; Li, K.; Li, J.; Yin, H. Biochemical characterization and evolutionary analysis of a novel pectate lyase from Aspergillus parasiticus. International Journal of Biological Macromolecules 2020, 152, 180-188. https://doi.org/10.1016/j.ijbiomac.2020.02.279.

16. Kashyap, D.R.; Vohra, P.K.; Chopra, S.; Tewari, R. Applications of pectinases in the commercial sector: A review. Bioresource Technology 2001, 77, 215-227. https://doi.org/10.1016/S0960-8524(00)00118-8.

17. Najafian, L.; Ghodsvali, A.; Khodaparast, M.H.H.; Diosady, L.L. Aqueous extraction of virgin olive oil using industrial enzymes. Food Research International 2009, 42,171-175. https://doi.org/10.1016/j.foodres.2008.10.002.

18. Chen, Q.; Jin, Y.; Zhang, G.; Fang, Y.; Xiao, Y.; Zhao, H. Improving production of bioethanol from duckweed (Landoltia punctata) by pectinase pretreatment. Energies 2012, 5, 3019-3032. https://doi.org/10.3390/en5083019.

19. Praveen, K.G.; Suneetha, V. A cocktail enzyme - Pectinase from fruit industrial dump sites: a review. 
Biological Chemical Science 2014, 5, 1252-1258.

20. Garg, G.; Singh, A.; Kaur, A.; Singh, R.; Kaur, J.; Mahajan, R. Microbial pectinases: an ecofriendly tool of nature for industries. 3 Biotech 2016, 6, 1-13. https://doi.org/10.1007/s13205-016-0371-4.

21. da Câmara Rocha, J.; da Silva Araújo, J.; de Paiva, W.K.V.; Ribeiro, E.S.S.; de Araújo Padilha, C.E.; de Assis, C.F.; dos Santos, E.S.; de Macêdo, G.R.; de Sousa Junior, F.C. Yellow mombin pulp residue valorization for pectinases production by Aspergillus niger IOC 4003 and its application in juice clarification. Biocatalysis and Agricultural Biotechnology 2020, 30, 101876. https://doi.org/10.1016/j.bcab.2020.101876.

22. Carr, J.G. ea, coffee and cocoa, In: B.J.B. Wood (Editor), Microbiology of fermented foods, London Elsevier Sci. Ltd. 1985; 2, 133-154.

23. Uzuner, S.; Çekmecelioğlu, D. Gıda Atıklarının Pektinaz Enzimi Üretiminde Kullanımı. Gıda / Journal Food 2016, 41, 259-266. doi: 10.15237/gida.GD15076

24. Onem, H.; Nadaroglu, H. Preparation and Properties of Purified Phytase from Oakbug Milkcap (Lactarius Quietus) Immobilised on Coated Chitosan with Iron Nano Particles and Investigation of Its Usability in Food Industry. Journal of Food Nutrition Research 2014, 2, 938-945. https://doi.org/10.12691/jfnr-2-12-13.

25. Nadaroglu, H., Sonmez, Z. Purification of an endo-beta 1,4-Mannanase from Clitocybe geotropa and immobilization on chitosan-coated magnetite nanoparticles: Application for fruit juices. Digest Journal of Nanomaterial and Biostructures 2016, 11, 685-697.

26. Dal Magro, L.; Kornecki, J.F.; Klein, M.P.; Rodrigues, R.C.; Fernandez-Lafuente, R. Pectin lyase immobilization using the glutaraldehyde chemistry increases the enzyme operation range. Enzyme Microbial and Technology 2020, 132, 109397. https://doi.org/10.1016/j.enzmictec.2019.109397.

27. Lee, S.W.; Cheon, S.A.; Il Kim, M.; Park, T.J. Organic-inorganic hybrid nanoflowers: Types, characteristics, and future prospects. Journal of Nanobiotechnology 2015, 13. https://doi.org/10.1186/s12951-015-0118-0.

28. Woo, P.C.Y.; Fung, A.M.Y.; Lau, S.K.P.; Yuen, K.Y. Identification by 16S rRNA gene sequencing of Lactobacillus salivarius bacteremic cholecystitis. Journal of Clinical Microbiology 2002, 40, $265-267$. https://doi.org/10.1128/JCM.40.1.265-267.2002.

29. Forsman, P.; Tilsala-Timisjärvi, A.; Alatossava, T. Identification of Staphylococcal and Streptococcal causes of bovine mastitis using 16S-23S rRNA spacer regions. Microbiology 1997, 143, 3491-3500. https://doi.org/10.1099/00221287-143-11-3491.

30. Garbers, I.M.; Britz, T.J.; Witthuhn, R.C. PCR-based denaturing gradient gel electrophoretictypification and identification of the microbial consortium present in kefir grains. World Journal of Microbiology and Biotechnology 2004, 20, 687-693. https://doi.org/10.1007/s11274-004-2624-3.

31. Taragano, V.M.; Pilosof, A.M.R. Application of Doehlert designs for water activity, pH, and fermentation time optimization for Aspergillus niger pectinolytic activities production in solid-state and submerged fermentation. Enzyme and Microbial Technology 1999, 25, 411-419. https://doi.org/10.1016/S01410229(99)00065-4.

32. Nadaroğlu, H.; Taşkin, E.; Adigüzel, A.; Güllüce, M.; Demir, N. Production of a novel pectin lyase from Bacillus pumilus (P9), Purification and characterisation and fruit juice application. Romanian Biotechnological Letters 2010, 15, 5167-76.

33. Sharma, A.; Gupta, M.N. Purification of pectinases by three-phase partitioning. Biotechnological Letter 2001, 23, 1625-1627. https://doi.org/10.1023/A:1011984517432.

34. Nedjma, M.; Hoffmann, N.; Belarbi, A. Selective and sensitive detection of pectin lyase activity using a colorimetric test: Application to the screening of microorganisms possessing pectin lyase activity. Analitical Biochemistry 2001, 291, 290-296. https://doi.org/10.1006/abio.2001.5032.

35. Bradford, M.M. A rapid and sensitive method for the quantitation of microgram quantities of protein utilizing the principle of protein-dye binding. Anal. Biochem. 1976, 72, 248-254. https://doi.org/10.1016/00032697(76)90527-3.

36. Nadaroglu, H.; Adiguzel, A.; Adiguzel, G. Purification and Characterization Of B-Mannanase from Lactobacillus plantarum (M24) and Its Applications In Some Fruit Juices. International Journal of Food Science and Technology 2015, 50, 1158-1165. https://doi.org/10.1111/ijfs.12739.

37. Lineweaver, H.; Burk, D. The Determination of Enzyme Dissociation Constants. Journal of American Chemical Society 1934, 56, 658-666. https://doi.org/10.1021/ja01318a036.

38. Kolcuoğlu, Y.; Colak, A.; Faiz, O.; Belduz, A.O. Cloning, expression and characterization of highly thermoand pH-stable maltogenic amylase from a thermophilic bacterium Geobacillus caldoxylosilyticus TK4. Process Biochemistry 2010, 45, 821-828. https://doi.org/10.1016/j.procbio.2010.02.001.

39. Ge, J.; Lei, J.; Zare, R.N. Protein-inorganic hybrid nanoflowers. Nat. Nanotechnol. 2012, 7, 428-432. 
https://doi.org/10.1038/nnano.2012.80.

40. Buchanan, R.E.; Gibbons, N.E. Bergey‘s Manual of Determinative Bacteriology, Eight edition, U.S.A., 1974.

41. Priest, F.G. Systematics and ecology of Bacillus. In Bacillus subtilis and other Gram-positive bacteria: Biochemistry Physiology and Molecular Genetics., Eds. A.L., Washington DC. American Society for Microbiology, 1993.

42. Parvathi, A.; Krishna, K.; Jose, J.; Joseph, N.; Nair, S. Biochemical and molecular characterization of Bacillus pumilus isolated from coastal environment in Cochin, India. Brazilian Journal of Microbiology 2009, 40, 269-275.

43. Yadav, S.; Yadav, P.K.; Yadav, D.; Yadav, K.D.S. Purification and characterization of an alkaline pectin lyase from Aspergillus flavus. Process Biochemistry 2008, 43, 547-552. https://doi.org/10.1016/j.procbio.2008.01.015.

44. Rasheedha Banu A.; Kalpana Devi, M.; Gnanaprabhal, G. R. Production and characterization of pectinase enzyme from Penicillium chrysogenum, Indian Journal of Science and Technology 2010, 3, 377-381. https://doi.org/10.17485/ijst/2010/v3i4/29721.

45. Sojitra, U. V.; Nadar, S.S.; Rathod, V.K. A magnetic tri-enzyme nanobiocatalyst for fruit juice clarification. Food Chemistry 2016, 213, 296-305. https://doi.org/10.1016/j.foodchem.2016.06.074.

46. Rios-Corripio, G.; Welti-Chanes, J.; Rodríguez-Martínez, V.; Guerrero-Beltrán, J.Á. Influence of high hydrostatic pressure processing on physicochemical characteristics of a fermented pomegranate (Punica granatum L.) beverage. Innov. Food Sci. Emerg. Technol. 2020, 59, 102249. https://doi.org/10.1016/j.ifset.2019.102249.

47. Wang, J.; Wang, J.; Vanga, S.K.; Raghavan, V. High-intensity ultrasound processing of kiwifruit juice: Effects on the microstructure, pectin, carbohydrates and rheological properties. Food Chemistry 2020, 313, 126121. https://doi.org/10.1016/j.foodchem.2019.126121.

48. Liu, J.; Bi, J.; McClements, D.J.; Liu, X.; Yi, J.; Lyu, J.; Zhou, M.; Verkerk, R.; Dekker, M.; Wu, X.; Liu, D. Impacts of thermal and non-thermal processing on structure and functionality of pectin in fruit- and vegetablebased products: A review. Carbohydrate Polymer 2020, 250, 116890. https://doi.org/10.1016/j.carbpol.2020.116890.

49. Mansel, B.W.; Ryan, T.M.; Chen, H.-L.; Lundin, L.; Williams, M.A.K. Polysaccharide conformations measured by solution state X-ray scattering. Chemical Physics Letters 2020, 739, 136951. https://doi.org/10.1016/j.cplett.2019.136951. 